Supporting information

\title{
Exonuclease III-powered self-propelled DNA machine for distinctly amplified detection of nucleic acid and protein
}

Shuang Liu, Xiaoxiao Yu, Jialong Wang, Dengren Liu, Li Wang, Shufeng Liu*

Key Laboratory of Optic-electric Sensing and Analytical Chemistry for Life Science, Ministry of Education, College of Chemistry and Molecular Engineering, Qingdao University of Science and Technology, 53 Zhengzhou Road, Qingdao 266042, China.

* Corresponding author. E-mail: sliu@qust.edu.cn

\section{Table of contents}

Nucleic acid sequence (Table S1)---------------------------------------------------------S2

Nucleic acid detection performance comparison (Table S2) ---------------------S3

Thrombin detection performance comparison (Table S3)------------------------S4

Fluorescence spectra of $\mathrm{H} 1$ before and after annealing with BHQ-free H2

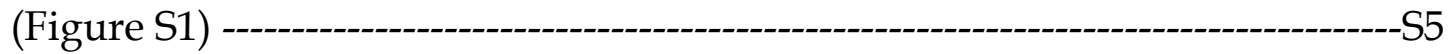

Optimization of Exo III and H1-H2 hybrid amount (Figure S2)------------------S6

Schematic illustration; fluorescence spectra for TD2 detection; gel electrophoresis; fluorescence responses at different inputs (Figure S3)--------S7

Fluorescence spectra and gel electrophoresis of the sensing system of the

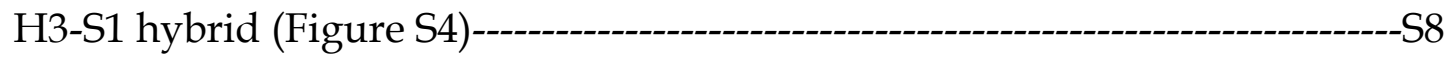

Gel electrophoresis for thrombin detection (Figure S5)---------------------------S9

Schematic illustration; detection performance toward thrombin by the H3-S1 hybrid probe (Figure S6)------------------------------------------------------------------S10

Detection selectivity toward thrombin (Figure S7)-------------------------------S11

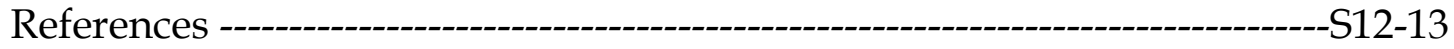


Table S1. The DNA sequences used in current study a

\begin{tabular}{|c|c|}
\hline Name & Sequence $\left(5^{\prime}\right.$ to $\left.3^{\prime}\right)$ \\
\hline H1 & $\begin{array}{l}\text { CGCATCTCTT(FAM)ACACGTGATCGAATGTTATTAATACCG } \\
\text { TAGTTGACCTATTCCCGACCCTAGAGATGCG }\end{array}$ \\
\hline $\mathrm{H} 2$ & $\begin{array}{l}\text { CAGAGGGTCGGGAATAGGTCAACTACGGTATTAATAACAT } \\
\text { TCGATCACGTGT(BHQ)AAGAGATGACCCTCTG }\end{array}$ \\
\hline BHQ-free H2 & $\begin{array}{l}\text { CAGAGGGTCGGGAATAGGTCAACTACGGTATTAATAACAT } \\
\text { TCGATCACGTGTAAGAGATGACCCTCTG }\end{array}$ \\
\hline H3 & $\begin{array}{l}\text { ATCTCTT(FAM)ACACGTGATCGAATGTTATTAATACCGTAG } \\
\text { ITGACCTATTCCCGACCCTAGAGATGCG }\end{array}$ \\
\hline S1 & $\begin{array}{l}\text { AGGGTCGGGAATAGGTCAACTACGGTATTAATAACATTCG } \\
\text { ATCACGTGT(BHQ)AAGAGATCTGGGACTG }\end{array}$ \\
\hline $\mathrm{H} 4$ & $\begin{array}{l}\text { TTTTCGCATCTCTACCAACCACACCTTTTTTTTTTTTTTTTTT } \\
\text { ITTTGGTTGGTGTGGTTGGTAGAGATTTTTTT }\end{array}$ \\
\hline $\begin{array}{l}\text { Target DNA } \\
\quad(\mathrm{TD} 1)\end{array}$ & GACCACCGCATCTCTACATTCAA \\
\hline $1 \mathrm{MT}$ & GACCACCGCAT TCTACATTCAA \\
\hline $2 \mathrm{MT}$ & GACCACC CATC CTACATTCAA \\
\hline $\mathrm{NC}$ & GACCACATGGATCTAGTATTCAA \\
\hline $\begin{array}{l}\text { Target DNA } \\
\text { (TD2) }\end{array}$ & CAAGATCAGAGGGTCACTTAGAA \\
\hline
\end{tabular}

\begin{abstract}
${ }^{a}$ For H1, the green color represents the base sequences of domains $\mathrm{c}$ and $\mathrm{c}^{*}$ in Scheme 1; the violet color represents the base sequences of domains of $\mathrm{d}$ and $\mathrm{d}^{*}$; the red color represents the base sequences of domain a; the blue color represents the base sequences of domain b. For H2, the dark yellow color represents the base sequences of domains e and $\mathrm{e}^{*}$; the red color represents the base sequences of domains of a and $\mathrm{a}^{*}$; the green color represents the base sequences of domain $c$; the blue color represents the base sequences of domain $b^{*}$. For H3, S1 and H4, different domains are also indicated with different colors, which are related with the schemes in Figure $3 \mathrm{~A}$ and $4 \mathrm{~A}$. The H1-H2 hybrid probe was obtained by annealing H1 with H2. The H3-S1 hybrid probe was obtained by annealing $\mathrm{H} 3$ with $\mathrm{S} 1$. The $\mathrm{H} 4$ is for thrombin aptamer switch. Target DNA (TD1) could recognize with the 3 '-protruding domain of $\mathrm{H} 1$ in $\mathrm{H} 1-\mathrm{H} 2$ hybrid probe or the $3^{\prime}$-protruding domain of $\mathrm{H} 3$ in H3-S1 hybrid probe. The 1MT and 2MT represents the one-base and two-bases mismatched DNA. The mismatched bases in contrast with target DNA (TD1) have been indicated with red color. The target DNA (TD2) could be recognized by 3'-protruding domain of $\mathrm{H} 2$ in $\mathrm{H} 1-\mathrm{H} 2$ hybrid probe. The recognition regions for TD1 and TD2 were indicated with green color.
\end{abstract}


Table S2. Comparison of detection performance for target DNA by current sensing system with those reported methods

\begin{tabular}{|c|c|c|c|}
\hline Ref. & Detection range & $\begin{array}{l}\text { Detection } \\
\text { limit }\end{array}$ & Strategy \\
\hline [1] & $1 \mathrm{fM}-0.1 \mathrm{nM}$ & $1 \mathrm{fM}$ & $\begin{array}{l}\text { Target recycling and cascade circular } \\
\text { exponential amplification }\end{array}$ \\
\hline [2] & $10 \mathrm{pM}-0.15 \mu \mathrm{M}$ & $10 \mathrm{pM}$ & $\begin{array}{l}\text { Palindromic molecular beacon-based } \\
\text { intramolecular strand-displacement } \\
\text { amplification }\end{array}$ \\
\hline [3] & $0.1 \mathrm{pM}-200 \mathrm{nM}$ & $16 \mathrm{fM}$ & $\begin{array}{l}\text { Target self-amplification-based DNA } \\
\text { machine }\end{array}$ \\
\hline [4] & $1 \mathrm{fM}-100 \mathrm{fM}$ & $0.75 \mathrm{fM}$ & $\begin{array}{l}\text { Exonuclease III-induced isothermal } \\
\text { amplification }\end{array}$ \\
\hline [5] & $100 \mathrm{fM}-10 \mathrm{nM}$ & $21 \mathrm{fM}$ & $\begin{array}{l}\text { Exonuclease III-assisted recycling and } \\
\text { DNAzyme }\end{array}$ \\
\hline [6] & $0.025 \mathrm{nM}-500 \mathrm{nM}$ & $15 \mathrm{pM}$ & $\begin{array}{l}\text { Exonuclease III-assisted upconversion } \\
\text { resonance energy transfer }\end{array}$ \\
\hline [7] & $10 \mathrm{fM}-1 \mathrm{nM}$ & $3 \mathrm{fM}$ & $\begin{array}{l}\text { Exonuclease III-assisted multiple cycle } \\
\text { amplification }\end{array}$ \\
\hline $\begin{array}{l}\text { This } \\
\text { work }\end{array}$ & $0.5 \mathrm{fM}-1 \mathrm{pM}$ & $0.1 \mathrm{fM}$ & $\begin{array}{l}\text { Exonuclease III-powered self-propelled } \\
\text { DNA amplification }\end{array}$ \\
\hline
\end{tabular}


Table S3. Comparison of detection performance for thrombin by current sensing system with those reported methods

\begin{tabular}{|c|c|c|c|}
\hline Ref. & Detection range & $\begin{array}{l}\text { Detection } \\
\text { limit }\end{array}$ & Strategy \\
\hline$[8]$ & $0.28 \mathrm{nM}-86 \mathrm{nM}$ & $30 \mathrm{pM}$ & $\begin{array}{l}\text { Exonuclease I assisted target recycling } \\
\text { and SYBR Green I }\end{array}$ \\
\hline [9] & $0.1 \mathrm{pM}-5 \mathrm{nM}$ & $23 \mathrm{fM}$ & $\begin{array}{l}\text { Binding induced 3D-bipedal DNA } \\
\text { walker and catalytic hairpin assembly }\end{array}$ \\
\hline [10] & $0.01 \mathrm{nM}-50 \mathrm{nM}$ & $6.9 \mathrm{pM}$ & $\begin{array}{l}\text { Aptamer structure switching and } \\
\text { metal-ion dependent DNAzyme }\end{array}$ \\
\hline [11] & $20 \mathrm{pM}-200 \mathrm{pM}$ & $9.2 \mathrm{pM}$ & Hybridization chain reaction \\
\hline [12] & $5 \mathrm{pM}-1 \mathrm{nM}$ & $1 \mathrm{pM}$ & $\begin{array}{l}\text { DNAzyme and entropy-driven } \\
\text { amplification }\end{array}$ \\
\hline [13] & $0.1 \mathrm{pM}-10 \mathrm{pM}$ & $56 \mathrm{fM}$ & $\begin{array}{l}\text { electrochemical ratiometric method } \\
\text { and DNA walker strategy }\end{array}$ \\
\hline [14] & $7.5 \mathrm{fM}-25 \mathrm{nM}$ & $2.2 \mathrm{fM}$ & $\begin{array}{l}\text { Dual-aptamer biorecognition and } \\
\text { mesoporous silica encapsulated with } \\
\text { iron porphyrin }\end{array}$ \\
\hline [15] & 20 pM-1 nM & $8.3 \mathrm{pM}$ & $\begin{array}{l}\text { Proximity recognition-dependent } \\
\text { strand translocation strategy with } \\
\text { catalytic hairpin assembly }\end{array}$ \\
\hline $\begin{array}{l}\text { This } \\
\text { work }\end{array}$ & $5 \mathrm{fM}-10 \mathrm{pM}$ & $5 \mathrm{fM}$ & $\begin{array}{l}\text { Exonuclease III-powered self-propelled } \\
\text { DNA amplification }\end{array}$ \\
\hline
\end{tabular}




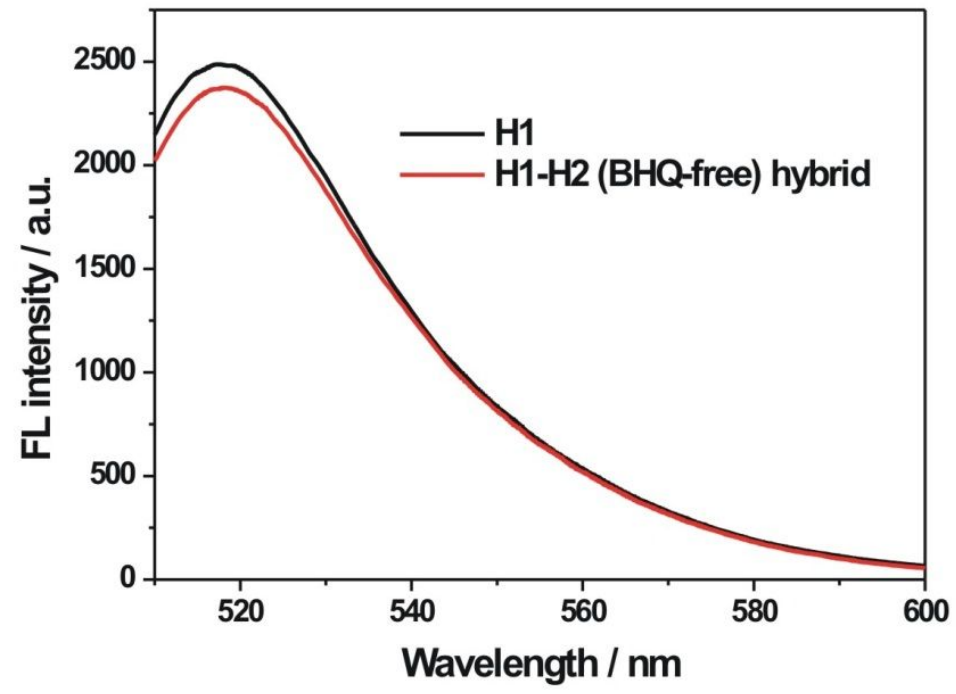

Figure S1. Fluorescence spectra recorded for H1 (200 nM) before and after annealing with $200 \mathrm{nM}$ BHQ-free H2. 

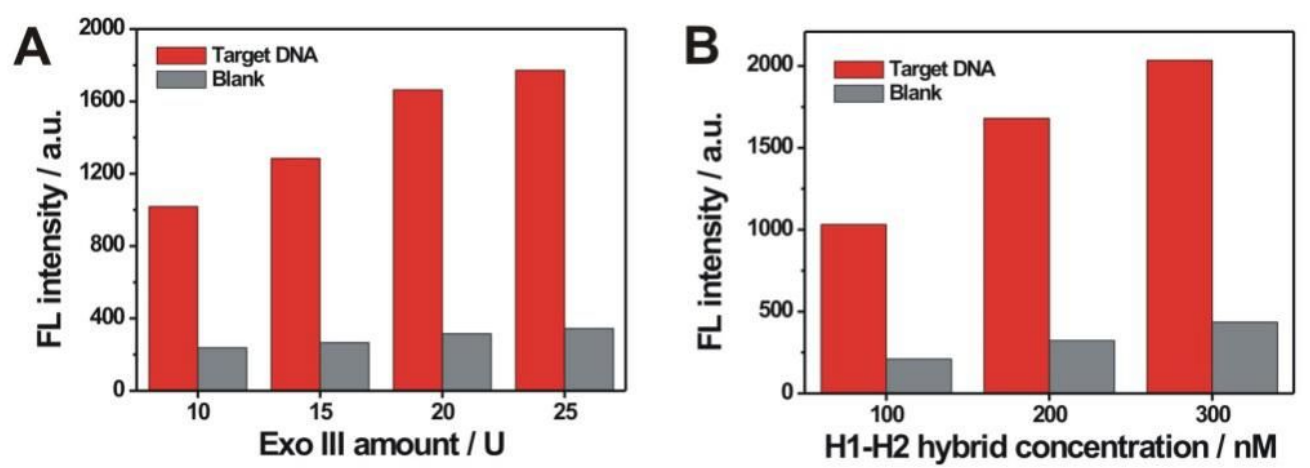

Figure S2. (A) Optimization of Exo III amount. Four different Exo III amounts (10, 15, 20 and $25 \mathrm{U})$ were used. (B) Optimization of H1-H2 hybrid concentration. Three different H1-H2 hybrid concentrations (100 nM, $200 \mathrm{nM}$ and $300 \mathrm{nM}$ ) were studied. Target DNA concentration and reaction time was $0.1 \mathrm{pM}$ and $60 \mathrm{~min}$, respectively. 


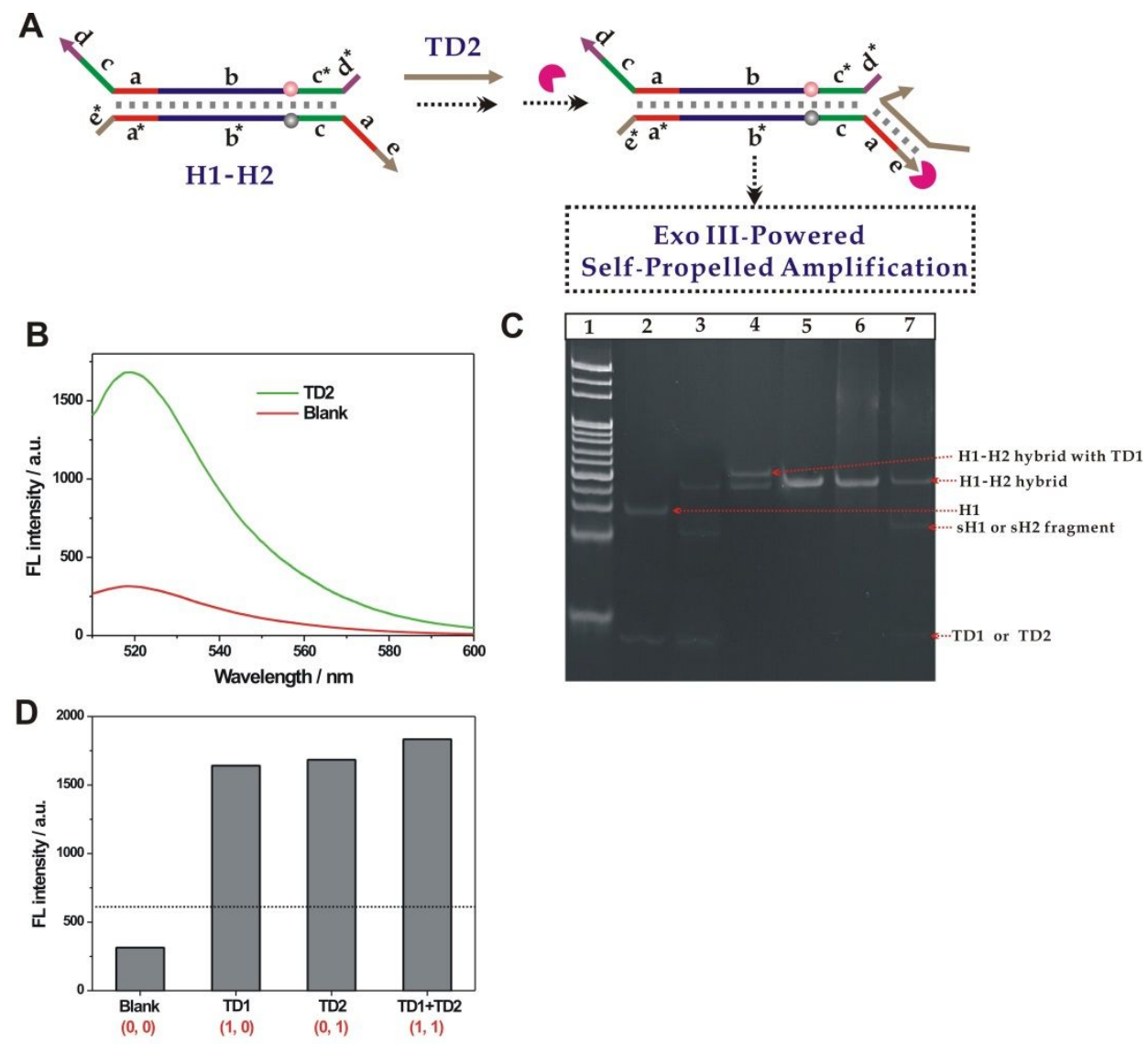

Figure S3. (A) Schematic illustration of the $\mathrm{H} 1-\mathrm{H} 2$ hybrid probe for the sensing of target DNA 2 (TD2). TD2 was recognized by the protruding 3'-domain of H2 in H1-H2 hybrid to trigger the successive Exo III-powered self-propelled DNA amplification process. (B) Fluorescence spectra of the sensing system in the presence and absence of $0.1 \mathrm{pM}$ TD2. (C) Gel electrophoresis images: lane 1, DNA maker; lane 2, TD1 + H1; lane 3, TD1 + H1-H2 hybrid + Exo III; lane 4, TD1 + H1-H2 hybrid; lane 5, H1-H2 hybrid; lane 6, H1-H2 hybrid + Exo III; lane 7, TD2 + H1-H2 hybrid + Exo III. (D) Fluorescence responses of the sensing system by $\mathrm{H} 1-\mathrm{H} 2$ hybrid toward different inputs including no TD1 and TD2, TD1 only, TD2 only, and both TD1 and TD2. TD1 represents target DNA that could recognize with the protruding 3'-domain of H1 in H1-H2 hybrid. TD2 could recognize with the protruding 3 '-domain of $\mathrm{H} 2$ in H1-H2 hybrid. The concentrations of TD1 and TD2 were both $0.1 \mathrm{pM}$. 

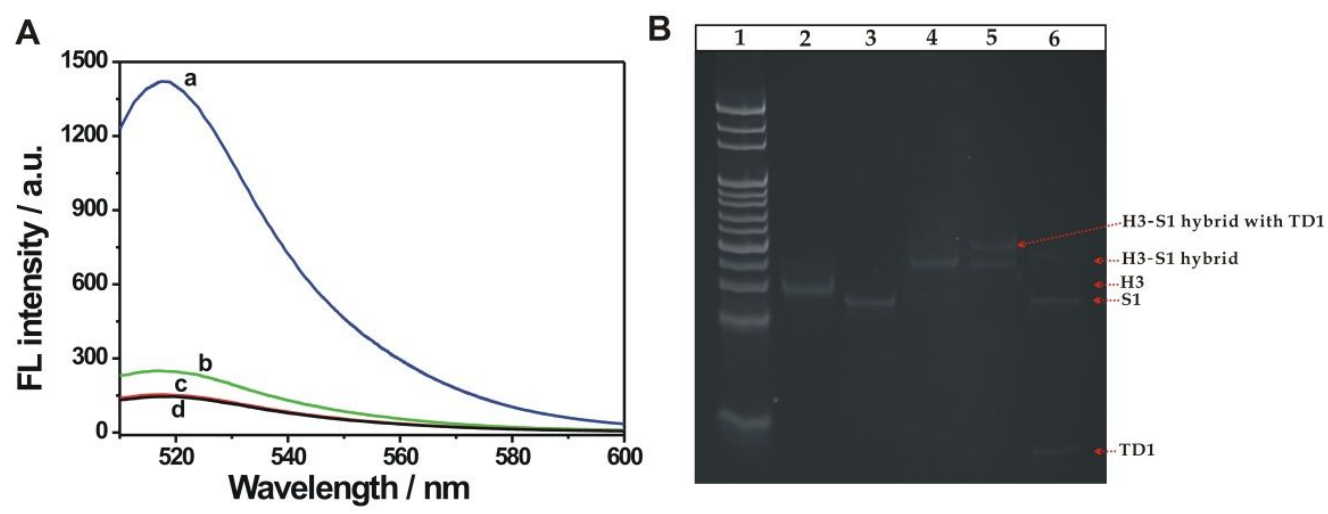

Figure S4. (A) Fluorescence spectra of the sensing system containing $200 \mathrm{nM}$ H3-S1 hybrid probe and $20 \mathrm{U}$ Exo III in the absence (b) and presence (a) of 0.1 $\mathrm{nM}$ target DNA. Control experiments are also conducted in the case of no Exo III (c), and no Exo III and target DNA (d), respectively. (B) Gel electrophoresis images: lane 1, DNA maker; lane 2, H3; lane 3, S1; lane 4, H3-S1 hybrid; lane 5, H3-S1 hybrid + TD1; lane 6, H3-S1 hybrid + TD1 + Exo III. 


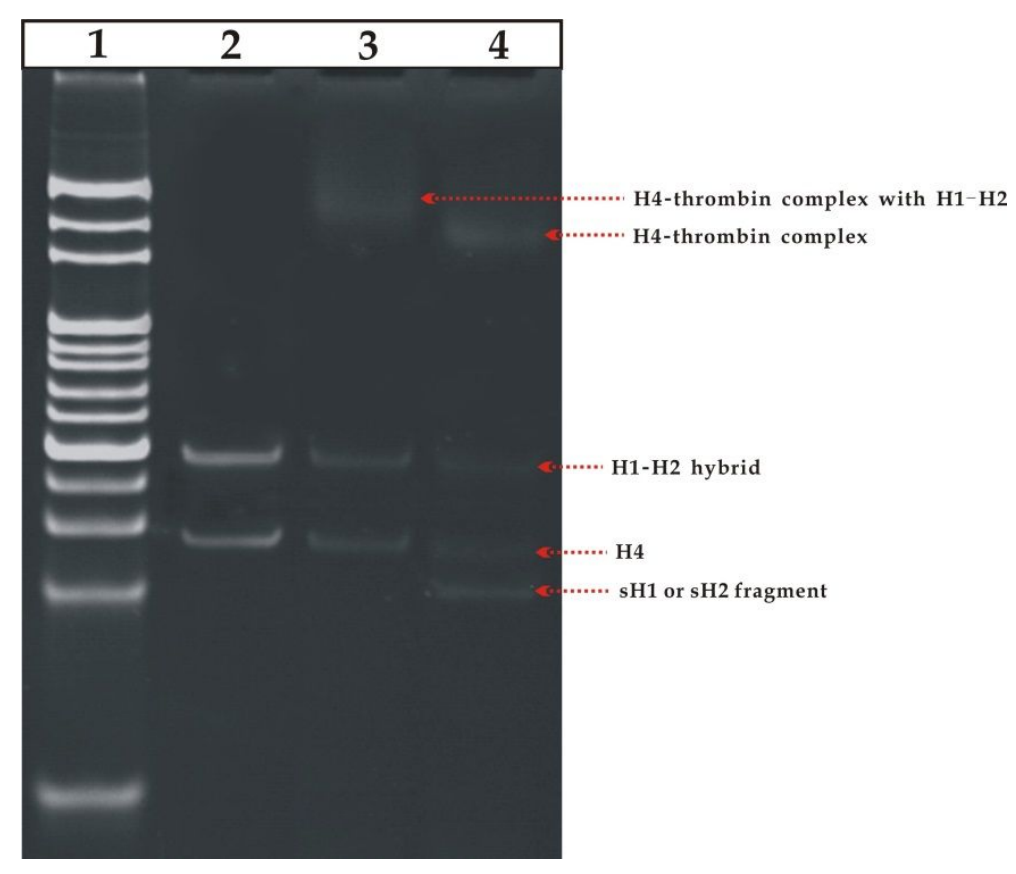

Figure S5. Gel electrophoresis images: lane 1, DNA maker; lane 2, H4 + $\mathrm{H} 1-\mathrm{H} 2$ hybrid; lane 3, H4 + H1-H2 hybrid + thrombin; lane 4, H4 + H1-H2 hybrid + thrombin + Exo III. 

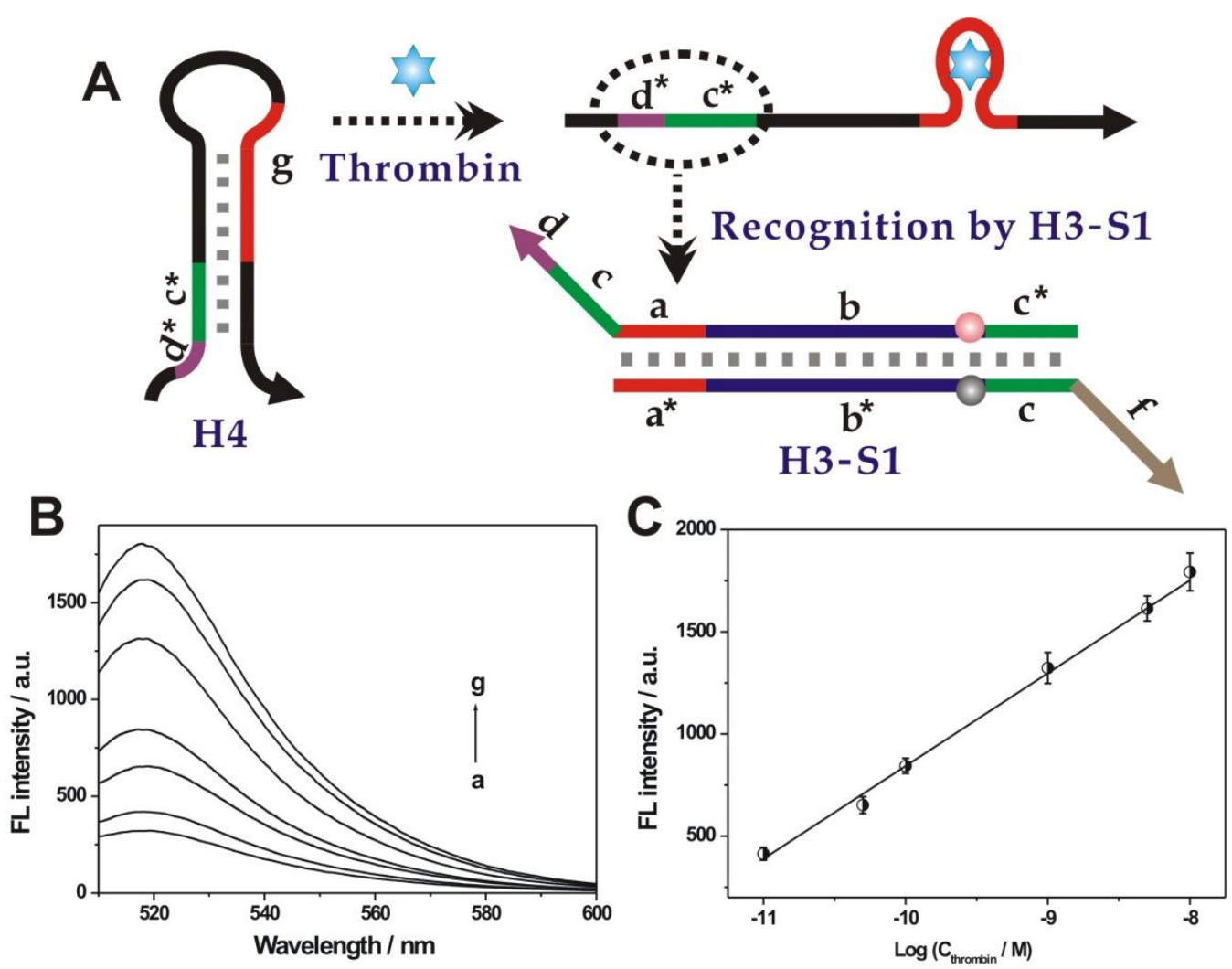

Figure S6. (A) Schematic illustration of thrombin detection by the sensing system of H3-S1 hybrid based on a typical Exo III-powered target recycling strategy. (B) Fluorescence spectra recorded at different concentrations of thrombin (from curves a to g: $0,10 \mathrm{pM}, 50 \mathrm{pM}, 100 \mathrm{pM}, 1 \mathrm{nM}, 5 \mathrm{nM}$, and 10 $\mathrm{nM}$, respectively). (C) Calibration curve for the fluorescence intensity vs thrombin concentration. 


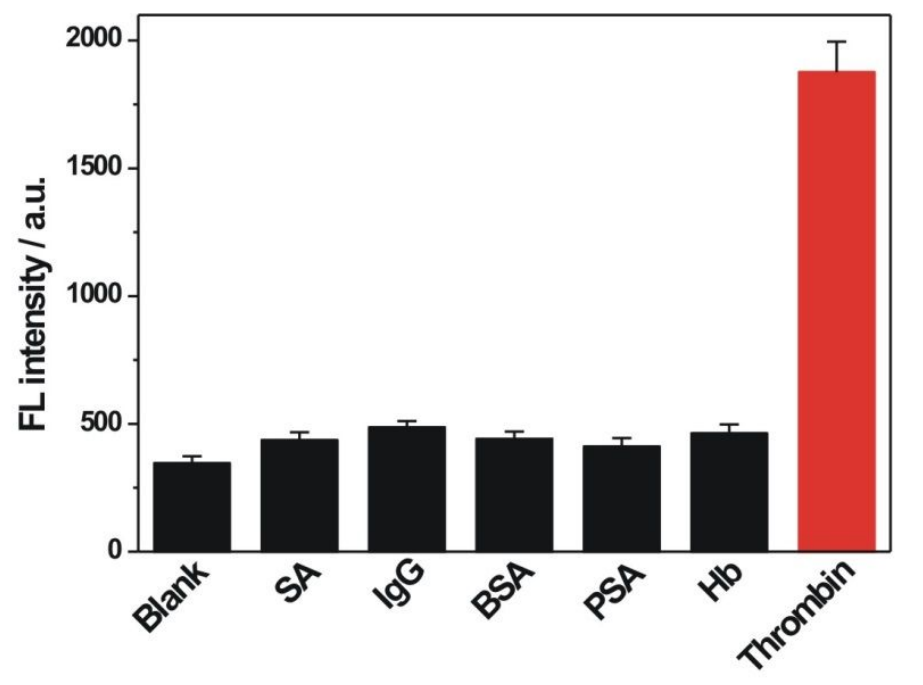

Figure S7. The selectivity of the sensing system (H1-H2 hybrid) toward thrombin and other non-specific proteins including streptavidin (SA), normal mouse immunoglobulin $\mathrm{G}(\mathrm{IgG})$, bovine serum albumin (BSA), prostate specific antigen (PSA), and Hemoglobin $(\mathrm{Hb})$. These proteins have a same concentration of $10 \mathrm{pM}$. 


\section{References}

[1] Sun, X.; Wang, L.; Zhao, M.; Zhao, C.; Liu, S. An Autocatalytic DNA Machine with Autonomous Target Recycling and Cascade Circular Exponential Amplification for One-Pot, Isothermal and Ultrasensitive Nucleic Acid Detection. Chem. Commun. 2016, 52, 11108-11111.

[2] Li, H.; Tang, Y.; Zhao, W.; Wu, Z.; Wang, S.; Yu, R. Palindromic Molecular Beacon-Based Intramolecular Strand-Displacement Amplification Strategy for Ultrasensitive Detection of K-ras Gene. Anal. Chim. Acta 2019, 1065, 98-106.

[3] Xu, H.; Jiang, Y.; Liu, D.; Liu, K.; Zhang, Y.; Yu, S.; Shen, Z.; Wu, Z. S. Twin Target Self-Amplification-Based DNA Machine for Highly Sensitive Detection of Cancer-Related Gene. Anal. Chim. Acta 2018, 1011, 86-93.

[4] Xue, Q.; Lv, Y.; Zhang, Y.; Xu, S.; Li, R.; Yue, Q.; Li, H.; Wang, L.; Gu, X.; Zhang, S.; Liu, J. Ultrasensitive Fluorescence Detection of Nucleic Acids Using Exonuclease III-Induced Cascade Two-Stage Isothermal Amplification-Mediated Zinc (II)-Protoporphyrin IX/G-Quadruplex Supramolecular Fluorescent Nanotags. Biosens. Bioelectron. 2014, 61, 351-356.

[5] Mu, Q.; Liu, G.; Yang, D.; Kou, X.; Cao, N.; Tang, Y.; Miao, P. Ultrasensitive Detection of DNA Based on Exonuclease III-Assisted Recycling Amplification and DNAzyme Motor. Bioconjugate Chem. 2018, 29, 3527-3531.

[6] Chen, Y.; Duong, H. T. T.; Wen, S.; Mi, C.; Zhou, Y.; Shimoni, O.; Valenzuela, S. M.; Jin, D. Exonuclease III-Assisted Upconversion Resonance Energy Transfer in a Wash-Free Suspension DNA Assay. Anal. Chem. 2018, 90, 663-668.

[7] Liu, W. J.; Xu, Q.; Ma, F.; Li, C. C.; Zhang, C. Y. Exonuclease III-Assisted Multiple Cycle Amplification for the Sensitive Detection of DNA with Zero Background Signal. Analyst 2018,143, 5461-5466.

[8] Chen, X.; Li, T.; Tu, X.; Luo, L. Label-Free Fluorescent Aptasensor for Thrombin Detection Based on Exonuclease I Assisted Target Recycling and SYBR Green I Aided Signal Amplification. Sensors and Actuators B 2018, 265, 98-103.

[9] Xiong, E.; Zhen, D.; Jiang, L.; Zhou, X. Binding-Induced 3D-Bipedal DNA Walker for Cascade Signal Amplification Detection of Thrombin Combined with Catalytic Hairpin Assembly Strategy. Anal. Chem. 2019, 91, 15317-15324.

[10] Li, J.; Wang, S.; Jiang, B.; Xiang, Y.; Yuan, R. Target-Induced Structure Switching of Aptamers Facilitates Strand Displacement for DNAzyme Recycling Amplification Detection of Thrombin in Human Serum. Analyst 2019, 144, 2430-2435.

[11] Huang, Z.; He, D.; Li, H. W. A Fluorometric Assay of Thrombin Using Magnetic Nanoparticles and Enzyme-Free Hybridization Chain Reaction. Microchim. Acta 2020, 187, 295.

[12] Yun, W.; Li, N.; Wang, R.; Yang, L.; Chen, L.; Tang, Y. Proximity Ligation Assay Induced Hairpin to DNAzyme Structure Switching for Entropy-Driven Amplified Detection of Thrombin. Anal. Chim. Acta 2019, 1064, 104-111.

[13] Zhu, C.; Liu, M.; Li, X.; Zhang, X.; Chen, J. A New Electrochemical Aptasensor for Sensitive Assay of a Protein Based on the Dual-Signaling Electrochemical Ratiometric Method and DNA Walker Strategy. Chem. 
Commun. 2018, 54, 10359-10362.

[14] Sun, Y.; Zhu, X.; Liu, H.; Dai, Y.; Han, R.; Gao, D.; Luo, C.; Wang, X.; Wei, Q. Novel Chemiluminescence Sensor for Thrombin Detection Based on Dual-Aptamer Biorecognition and Mesoporous Silica Encapsulated With Iron Porphyrin. ACS Appl. Mater. Interfaces 2020, 12, 5569-5577.

[15] Li, J.; Zhou, W.; Yuan, R.; Xiang, Y. Aptamer Proximity Recognition-Dependent Strand Translocation for Enzyme-Free and Amplified Fluorescent Detection of Thrombin via Catalytic Hairpin Assembly. Anal. Chim. Acta 2018, 1038, 126-131. 